\title{
DISTRIBUSI SEDIMEN DASAR SEBAGAI IDENTIFIKASI EROSI PANTAI DI KECAMATAN BREBES MENGGUNAKAN ANALISIS GRANULOMETRI
}

\section{BED SEDIMENT DISTRIBUTION FOR IDENTIFICATION OF THE COASTAL EROSION IN BREBES SUBDISTRICT USING GRANULOMETRI ANALYSIS}

\author{
Wisnu Arya Gemilang*, Ulung Jantama Wisha, Gunardi Kusumah \\ Loka Penelitian Sumber Daya dan Kerentanan Pesisir, Kementerian Kaluatan dan Perikanan \\ Jl. Raya Padang-Painan km. 16, Bungus, Padang, Sumatera Barat - 65245 \\ *Corresponding author e-mail: wisnu.gemilang@yahoo.co.id
}

Submitted: 24 November 2016 / Revised: 27 Februaril 2017 / Accepted: 25 April 2017

http://doi.org/10.21107/jk.v10i1.2156

\begin{abstract}
The dynamics of erosion and accretion in the coastal area of Brebes Subdistrict have many impacts on mangrove destruction and coastal region. The erosion and accretion are influenced by oceanography parameters that can affect the distribution of coastal sediments. The aims of this research were to determine the characteristics of the phenomenon of erosion and accretion in coastal Brebes Subdistrict and shape appropriate mitigation to reduce the erosion. This research is done with the bed sediment sampling using grab sampler for 26 sampling point. Current and tide measurement are conducted wih ADCP deployment for 15 days' measurement. Sediment characteristic analysis done with granulometri and statistic analysis. The average of sediment sorting is 1.21, skewness is 0.088 and the kurtosis is 3.76. Generally, bed surface sediment distribution pattern is dominated by clay to sand, the grand size distribution of sediments are sand, silt, sandy silt and silty sand. Longshore current speed ranged between 0-0.12 m.s. $\mathrm{s}^{-1}$ at the spring tide condition and ranged between 0-0.08 m.s $\mathrm{s}^{-1}$ at the neap tide condition, the domination of current direction towards to the East and Northeast. The mitigation is very needed to rearrange the mangrove areas, build the coastal protection and recover the main river line which is the sourceof the sediment materials, so that can be provide the supply of sediment deposition in the coastal area.
\end{abstract}

Keywords: Brebes, Erosion, Longshore Current, Mitigation, Sediment

\section{ABSTRAK}

Dinamika kawasan pesisir Kecamatan Brebes berupa bencana abrasi dan akresi yang terjadi memiliki dampak besar terhadap kerusakan kawasan mangrove dan pesisir. Fenomena erosi dan akresi yang terjadi dipengaruhi oleh parameter oseanografi yang dapat mempengaruhi sebaran sedimen di pesisir. Penelitian ini bertujuan untuk mengetahui karakteristik distribusi sedimen dasar perairan sebagai upaya identifikasi bencana erosi yang terjadi di pesisir Kecamatan Brebes. Penelitian dilakukan dengan pengambilan sampel sedimen dasar perairan menggunakan metode grab sampler terhadap 26 titik pengambilan. Pengukuran kecepetan arus di lokasi penelitian dilakukan dengan pemasangan ADCP selama 15 hari. Analisis karakteristik sedimen dilakukan dengan metode analisis granulometri dan statistic sedimen. Nilai rata-rata sortasi 1.21, skewness 0.088 dan kurtosis 3.76. Secara umum, pola sebaran sedimen permukaan dasar laut Kec.Brebes didominasi oleh sedimen berukuran lempung-pasir. Jenis sedimen berdasarkan ukuran butirnya yaitu pasir, pasir lanauan, lanau pasiran dan lanau. Kecepatan arus sepanjang pantai hasil model pada kondisi purnama berkisar 0-0,12 m.s. dan pada saat perbani berkisar antara 0-0,08 m.s. dengan dominasi arah arus menuju ke Timur dan Timur laut. Perlu dilakukan penataan ulang terhadap kawasan mangrove dan bangunan pelindung pantai serta melakukan pencodetan terhadap sungai - sungai utama yang merupakan sumber pembawa material sedimen sehingga dapat memberikan suplay endapan sedimen di bagian pesisir. 
Kata Kunci: Brebes, erosi, arus sepanjang pantai, mitigasi, sedimen

\section{PENDAHULUAN}

Bencana erosi sangat berkaitan erat dengan proses akresi yaitu sedimentasi pantai yang terjadi bila jumlah sedimen yang diendapkan lebih besar daripada kemampuan laut untuk mengangkut sedimen tersebut sehingga daratan pantai akan bertambah (Diposaptono dan Budiman, 2007). Upaya pengurangan area erosi secara alamiah dibutuhkan laju sedimentasi yang cukup besar pada daerah muara - muara sungai yang diperoleh dari aliran sungai yang membawa sedimen dari hulu dan selanjutnya akan terdeposit di bagian pesisir pantai yang mengalami Erosi. Erosi diperparah bila sedimen sungai yang menjadi penyeimbang tidak cukup mengganti sedimen yang tererosi (Helfinalis et al., 2010). Di Kec. Brebes, wilayah yang paling parah tingkat erosinya adalah Kaliwlingi dan Randusanga Kulon Kecamatan Brebes dan sebagian wilayah Desa Sawojajar Kecamatan Wanasari.

Perairan pantai Brebes merupakan pantai dangkal tersusun dari dataran alluvial akibat beberapa aktivitas sungai besar dan kecil yang bermuara di perairan tersebut. Perubahan sifat sungai baik di hulu maupun hilir mempengaruhi kondisi pantai termasuk terjadinya abrasi dan akresi pantai. Mangrove umumnya dijumpai di muara sungai berasosiasi dengan dataran lumpur dan pasir pantai (Dinas Kelautan dan Perikanan Provinsi Jawa Tengah, 2012). Wilayah pantai Kecamatan Brebes terbagi dalam tiga sedimen sel yaitu Sel I Pantai Randusanga sampai Tanjung (Delta Pemali) transport sedimen pada jalur ini bergerak dari barat ke timur, sel II Tanjung Brebes sampai dengan Teluk Bangsari transport sedimen bergerak dari arah timur ke barat dan sel III Teluk Bangsri sampai dengan Tanjung Losari (Delta Cisanggarung) transport sedimen bergerak dari arah barat ke timur (DKP Kab. Brebes, 2008).

Sifat-sifat sedimen yang penting untuk diketahui antara lain ukuran partikel dan butir sedimen, rapat massa, bentuk dan juga kecepatan sedimen (Bayhaqi dan Dungga, 2015). Ukuran butir adalah aspek yang paling fundamental dari partikel sedimen, yang mempengaruhi proses sedimentasi, transportasi dan pengendapan (Blott dan Kenneth, 2001). Analisis ukuran butir karena itu memberikan petunjuk penting asal sedimen, sejarah transportasi dan kondisi pengendapan (Folk dan Ward, 1957; Friedman, 1979; Bui et al., 1990). Distribusi ukuran butir dipengaruhi oleh faktor lain seperti jarak dari garis pantai, jarak dari sumber (sungai), sumber material sedimen, topografi dan mekanisme transportasi sedimen (Abuodha, 2003). Analisis granulometri adalah analisis ukuran butir sedimen. Analisis ini umumnya dilakukan untuk menentukan tingkat resistensi terhadap proses eksogenik butir sedimen, Sebagai contoh yaitu proses pelapukan, erosi, dan abrasi dari asalnya trasnportasi dan proses deposisi sedimen (Yasin et al., 2016).

Mekanisme transport sedimen di wilayah pantai sangat dipengaruhi oleh faktor osenaografi, dinamika perairan yang sangat fluktuatif menyebabkan tingkat turbulensi yang sangat besar, bila asupan sedimen dari sungai tidak seimbang dengan wilayah yang terjadi erosi dalam jangka panjang akan merubah keberadaan garis pantai. Longshore current merupakan faktor utama yang berperan dalam mekanisme transport di wilayah pantai, proses pengadukan oleh gerakan partikel arus menyebabkan sedimen dapat berpindah dari satu tempat ke tempat lain (Wisha dan Aida, 2016b).

Upaya mitigasi yang telah dilakukan oleh dinas terkait dan masyarakat dalam upaya mengurangi dampak erosi yang ada di pesisir Kecamatan Brebes diantaranya, pembangunan Hybrid Engineering (HE), penanaman mangrove pada kawasan pesisir, dumping stone, pembuatan Alat Pemecah Ombak (APO), Penataan Kawasan Pesisir (PKP) (DKP Kab. Brebes, 2015). Dalam lingkungan pesisir, sedimen bersifat dinamis yang akan mengalami pengikisan, transportasi dan pengendapan dalam skala spasial maupun temporal. Penyelidikan pemahaman tentang proses dinamis yang terjadi di lingkungan pesisir sangatlah diperlukan untuk prediksi evolusi pesisir dimasa datang (Winter, 2007). 
Oleh karena itu penelitian ini bertujuan untuk mengetahui karakteristik proses sedimentasi yang terjadi di kawasan pesisir Kecamatan Brebes serta mengetahui karakteristik hidrooseanografi yang terjadi. Berdasarkan hasil analisis grandulometri sedimen dasar perairan dan pengamatan faktor hidrooseanografi sehingga diharapkan dapat memberikan infromasi terkait pemilihan alat pelindung pantai yang tepat dalam upaya mengurangi bencana erosi pantai di Kecamatan Brebes.

\section{MATERI DAN METODE}

Kondisi geologi dan stratigrafi Kecamatan Brebes menurut Djuri et al. (1996) tersusun atas Qa (endapan alluvial) yang menyusun bagian pesisir dan dataran rendah di Kecamatan Brebes terdiri dari kerikil, pasir, lanau dan lempung sebagian endapan sungai dan pantai. Bagian Selatan Kecamatan Brebes tersusun atas Qls (endapan lahar Gunung Slamet), Tptl (Anggota Batugamping Fm. Tapak), Tmp (Fm. Pemali) tersusun atas napal bersisipan batugamping pasiran dan batupasir kasar. Penelitian ini berlokasi di perairan mulai dari muara sungai hingga menuju ke arah laut lepas yang ada di Kecamatan Brebes, Jawa Tengah dengan titik pengambilan sampel sebanyak 26 titik yang tersebar secara merata dari bagian Timur hingga Barat daerah penelitian (Gambar 1). Pengambilan sampel berdasarkan pada pembagian morfologi pesisir yaitu muara sungai, bagian depan beting gisik dan laut lepas untuk mengetahui masing-masing karakteristik sedimen tiap lokasi pengambilan sampel.

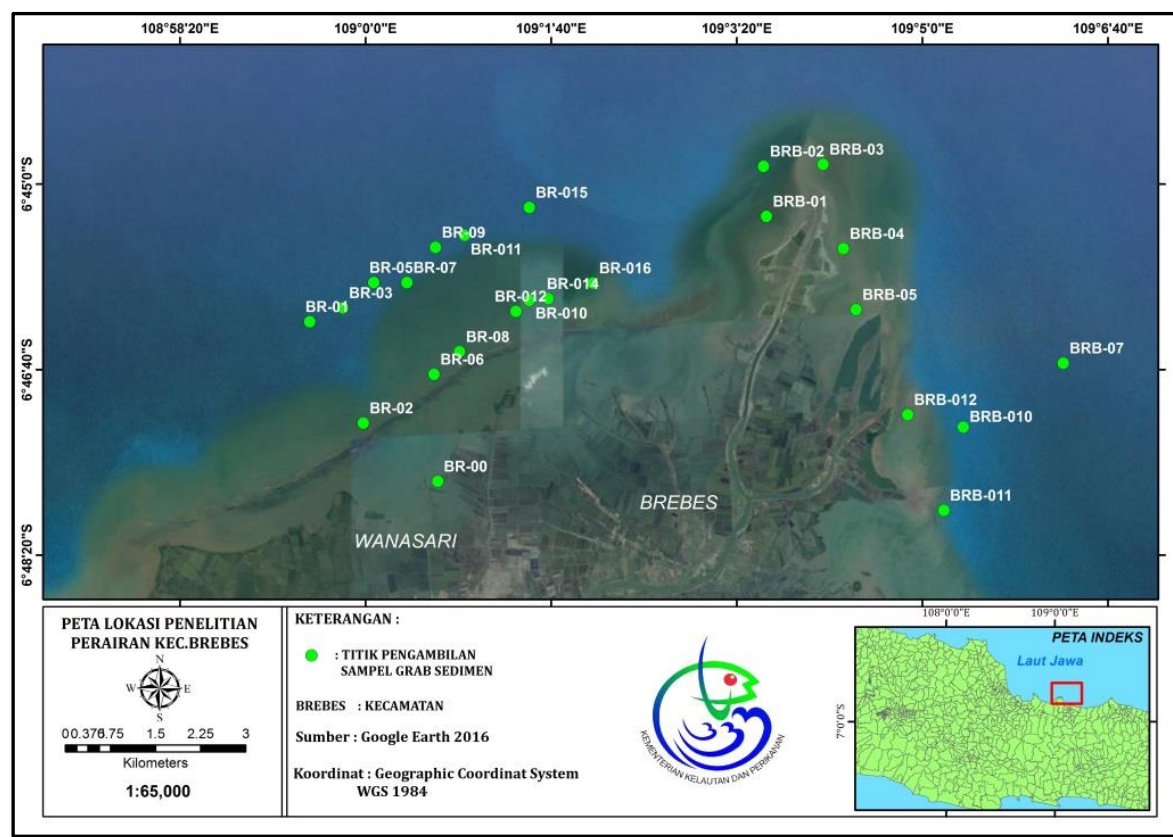

Gambar 1. Peta lokasi penelitian

Pengambilan sampel sedimen dasar menggunakan alat eckman grab sampler sehingga memungkinkan sampel sedimen bagian dasar terperangkap pada alat tersebut. Sedangkan metode analisis ukuran butir dan jenis sedimen menggunakan metode ayak kering pada saringan bertingkat (sieve analysis) serta analisis granulometri. Distribusi ukuran butir diketahui menggunakan metode granulometri (Hubbard dan Pocock, 1972; Hsieh, 1995). Penentuan jenis sedimen dilakukan berdasarkan klasifikasi Diagram Segitiga Shepard tahun 1954 (Dyer, 1986), sedangkan untuk menafsirkan sebaran, mekanisme pengangkutan dan pengendapan sedimen digunakan pendekatan statistik dari masing-masing kelompok sedimen. Analisis statistik sedimen berupa sorting, skewnees dan kurtosis menggunakan klasifikasi Flok dan Ward (1957), sedangkan perhitungannya menggunakan Software Microsoft Excel 2007 untuk menghitung persentase ukuran butir dan statistik sedimen. 
Pengukuran arus dan pasang-surut menggunakan alat ADCP (Nortek) (Tabel 1) yang diletakkan pada satu titik di lokasi penelitian selama 15 hari perekaman. Instrumen tersebut mencatat arus, pasang surut dan suhu perairan. Alat ADCP dipasang dengan jarak blanking $0,5 \mathrm{~m}$ setelah transduser. Spesifikasi ADCP dapat dilihat pada Tabel 1. Data hasil perekaman ADCP tersebut digunakan untuk validasi hasil permodelan (Wisha dan Aida, 2016b). Permodelan arus pasang surut dilakukan menggunakan modul Flow modelfm pada MIKE21 dan disimulasikan selama 15 hari, sehingga terlihat pengaruh pasang surut terhadap pembentukan dan pola arus di sepanjang perairan Brebes. Set-up permodelan hidrodinamika ditampilkan pada Tabel 2.

Tabel 1. Spesifikasi alat ADCP

\begin{tabular}{ll}
\hline Acoustic frequency & $0.6 \mathrm{MHz}$ \\
\hline Max profile range & $30-40 \mathrm{~m}$ \\
\hline Cell size & $1-4 \mathrm{~m}$ \\
\hline Minimum blanking distance & $0.50 \mathrm{~m}$ \\
\hline Max cell & 128 \\
\hline Velocity range & $\pm 10{\mathrm{~m} . \mathrm{s}^{-1}}^{-1} \%$ \\
\hline Accuracy & $1 \%$ of measured value $\pm 0.50{\mathrm{~m} . \mathrm{s}^{-1}}^{-1} \mathrm{~Hz}$ \\
\hline Max sampling range &
\end{tabular}

Tabel 2.Set-up permodelan hidrodinamika

\begin{tabular}{ll}
\hline Parameter & Diterapkan dalam simulasi \\
\hline Time of simulation & Number of time step $=2000$ \\
& Time step interval $=900$ \\
& Simulation start date $=1 / 5 / 201612.30 \mathrm{AM}$ \\
& Simulation end date $=15 / 5 / 201608.30 \mathrm{PM}$ \\
\hline Besh boundary & Bathymetry $=$ DISHIDROS map digitation \\
\hline Flood and dry & Drying depth $=0.005 \mathrm{~m}$ \\
& Flooding depth $=0.05 \mathrm{~m}$ \\
& Wetting depth $=0.1 \mathrm{~m}$ \\
\hline Boundary condition & Type $=$ Specified level \\
& Format = Varying in time, constant along boundary \\
& Time Series = Tide forecasting with coordinates below: \\
& 1. Longitude: 109.05297, Latitude: -6.7806 \\
2. Longitude: 109.05010, Latitude: -6.7665 \\
3. Longitude: 109.03086, Latitude: -6.7651 \\
4. Longitude: 109.01559, Latitude: -6.7773 \\
5. Longitude: 109.01882, Latitude: -6.7888 \\
\hline
\end{tabular}

\section{HASIL DAN PEMBAHASAN}

\section{Jenis Sedimen Perairan Kec. Brebes}

Data ukuran butir berdasarkan 26 sampel yang diambil dari perairan Kecamatan Brebes. Sampel sedimen yang telah dianalisis oleh dengan metode granulometri (ukuran butir sedimen) memperlihatkan variasi nilai dan persentase ukuran butir sedimen. Hasil analisis terhadap persentase ukuran butir sedimen dapat dilihat pada Diagram Segitiga Shepard 1954 (Gambar 3), sehingga dapat memudahkan untuk menginterpretasikan pengelompokan jenis sedimennya. Secara umum sedimen dasar laut yang ada di lokasi penelitian didominasi oleh ukuran lanau hingga pasir (Gambar 2). Penamaan jenis sedimen berdasarkan 
pengklasifikasian pada Diagram Segitiga Shepard 1954.

Secara umum berdasarkan persentase ukuran butir sedimen dapat terlihat bahwa jenis sedimen yang ada di perairan Kecamatan Brebes terbagi atas 4 jenis sedimen berdasarkan persentase ukuran butir sedimen clay, silt dan sand yaitu silt (lanau), sand (pasir), sandy silt (lanau pasiran), silty sand (pasir lanauan). Dominasi jenis sedimen lanau hingga lanau pasiran tersebar pada bagian Timur daerah penelitian yang merupakan bagian perairan laut yang berdekatan dengan muara sungai utama yang ada di Kecamatan Brebes yaitu Sungai Pemali dan Sungai Codetan. Kelompok jenis sedimen pasir, pasir lanauan hingga pasir lumpuran tersebar pada bagian Barat dasar perairan daerah penelitian. Bagian Barat daerah penelitian merupakan daerah yang memiliki morfologi beting gisik atau sering disebut sebagai Pulau Pasir oleh warga setempat yang berhadapan langsung dengan laut lepas, namun pada bagian batasan Barat daerah penelitian juga terdapat Muara Sungai Nipon.

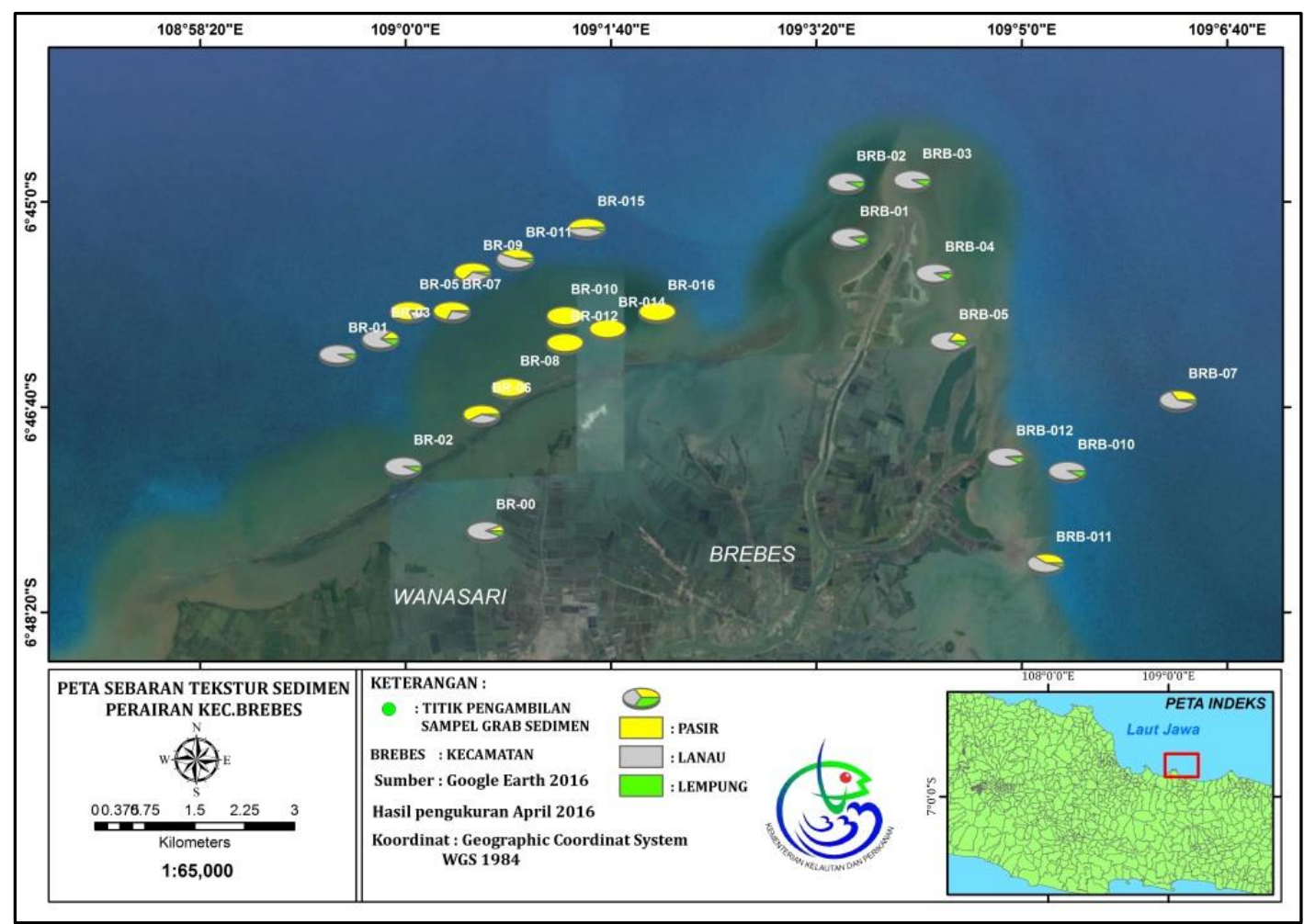

Gambar 2. Peta sebaran tekstur sedimen di perairan Kecamatan Brebes

Perbedaan ukuran butir sedimen berhubungan dengan asal sumber sedimen. Semakin kearah daratan atau dekat dengan muara sungai dan kawasan mangrove ukuran butir sedimen cenderung semakin halus, sedangkan ukuran butir yang berhadapan dengan laut lepas dan jauh dari muara sungai ukuran butir lebih kasar. Hal ini menunjukkan bahwa sumber sedimen berasal dari laut yang kemudian mengalami proses transportasi hingga akhirnya terendapkan menjadi sedimen di masing- masing lokasi. Selain itu ukuran butir lebih kasar diinterpretasikan merupakan hasil penggerusan beting gisik oleh gelombang kemudian tertransport pada bagian depan dasar perairan Kecamatan Brebes. Menurut Davis (1991) arus sungai yang memasuki air laut akan mengalami perlambatan. Akibatnya kemampuan mengangkut material berkurang sehingga material tersebut mengendap pada bagian mulut muara dan depan muara sungai. 


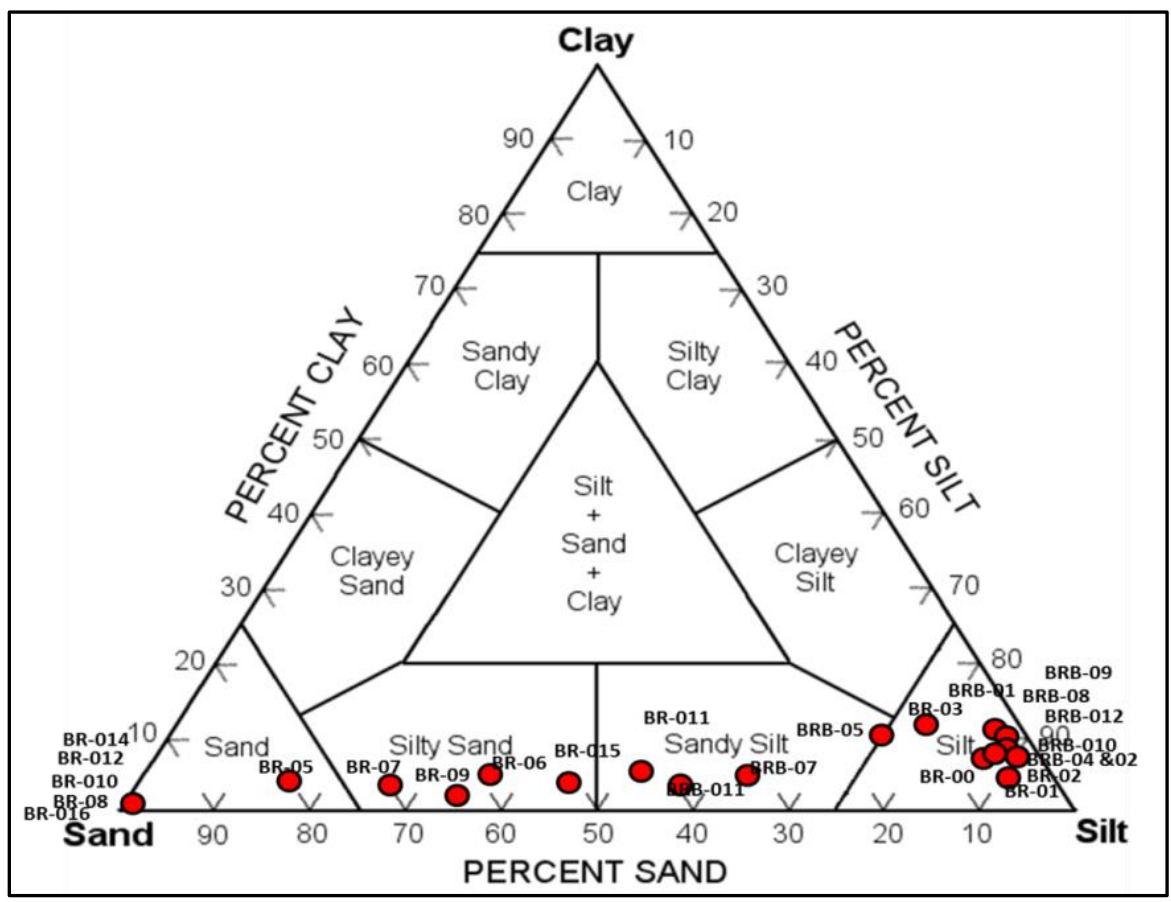

Gambar 3. Persentase dan jenis sedimen berdasarkan Diagram Segitiga Shepard 1954

\section{Interpretasi Statistik Ukuran Butir Sedimen}

Analisis statistik dalam parameter ukuran butir sedimen (sortasi, kurtosis dan skewness) merupakan salah satu metode yang digunakan untuk identifikasi proses terangkut dan terendapkan sedimen. Untuk memperoleh parameter ukuran butir maka dilakukan perhitungan statistika dengan hasil yang tercantum Tabel 3 .

Hasil analisis parameter ukuran butir menunjukkan bahwa perairan Kecamatan Brebes didominasi oleh lanau - pasir lanuan. Hal ini menunjukkan bahwa sedimen mengalami proses deposisi. Proses deposisi dicirikan dengan terendapkannya sedimen berukuran halus - kasar. Hasil perhitungan terhadap parameter statistik sedimen berupa sortasi menunjukkan nilai $0.54-1.91$ sehingga masuk dalam klasifikasi tingkat pemilahan buruk hingga terpilah sedang (Folk dan Ward, 1977).

Nilai sortasi sedimen di lokasi penelitian termasuk dalam pemilahan buruk hingga sedang, Ingmanson dan Wallace (1989) menjelaskan bahwa sedimen dengan granulometri terpilah buruk diakibatkan oleh ukuran partikel yang terakumulasi secara acak. Kondisi pemilahan butiran sedimen buruk dipengaruhi oleh kekuatan arus dan gelombang sangat tidak stabil, artinya kekuatannya tidak sama setiap saat sehingga butiran sedimen yang diendapkan berbeda sangat mencolok (Rifardi, 2012). Selain kondisi tersebut proses pertemuan antara arus sungai dengan arus laut menyebabkan terjadinya gradasi energi arus pengendapan sehingga menyebabkan kondisi energi arus yang fluktuatif dan ukuran butir sedimen tidak terpilah dengan baik.

Nilai kemencengan (skewness) pada 26 sampel sedimen dasar perairan Kecamatan Brebes menunjukkan variasi nilai yang berbeda-beda dengan kisaran -0.82 - 0.89 . Sehingga berdasarkan klasifikasi kemencengan daerah penelitian memiliki 5 jenis klasifikasi tingkat kemencengan butiran sedimen yaitu menceng halus, menceng simetris, menceng sangat halus, menceng sangat kasar dan menceng kasar. Hal ini menunjukkan bahwa sedimen telah mengalami proses transportasi dan mengendap pada kawasan perairan tersebut. Nilai kemencengan (skewness) yang didapat dari hasil perhitungan menunjukkan perbedaan tekstur sedimen antara stasiun. Perbedaan nilai kemencengan menggambarkan kekuatan energi yang bekerja di perairan tersebut tidak dominan sama, atau berubah ubah (Arjenggi et al., 2013). 
Kondisi skewness/kemencengan secara umum pada daerah penelitian masuk dalam kondisi positively skewed atau condong positif yang mengindikasikan bahwa kondisi dilokasi berada pada substrat berukuran halus yaitu lanau hingga lumpur dimana hal tersebut ditemukan dalam Surbakti (2010), bahwa skewness pada muara sungai berada pada kisaran rata-rata simetris, halus, hingga sangat halus. Nilai statistik sedimen berupa kurtosis menurut Darlan (1996) adalah gambaran hubungan sortasi bagian tengah dan bagian bawah dan hanya menunjukkan kriteria sedimen melalui grafik. Berdasarkan hasil perhitungan statistik sedimen nilai kurtosis daerah penelitian terdapat 2 jenis grafik kurtosis yaitu sangat runcing sekali dan sangat runcing.

Tabel 3. Hasil perhitungan statistik untuk parameter ukuran butir

\begin{tabular}{|c|c|c|c|c|c|c|}
\hline $\begin{array}{l}\text { Kode } \\
\text { Stasiun }\end{array}$ & Sortasi & Klasifikasi & Skewness & Klasifikasi & Kurtosis & Klasifikasi \\
\hline BR-00 & 1.18 & Terpilah buruk & 0.2 & Menceng halus & 3.06 & $\begin{array}{c}\text { Sangat runcing } \\
\text { sekali }\end{array}$ \\
\hline BR-01 & 1.32 & Terpilah buruk & 0.18 & Menceng halus & 2.72 & Sangat runcing \\
\hline BR-02 & 1.03 & Terpilah buruk & 0.13 & Menceng halus & 3.3 & $\begin{array}{l}\text { Sangat runcing } \\
\text { sekali }\end{array}$ \\
\hline BR-03 & 1.78 & Terpilah buruk & -0.07 & $\begin{array}{l}\text { Menceng } \\
\text { simetris }\end{array}$ & 2.48 & Sangat runcing \\
\hline BR-05 & 1.03 & Terpilah buruk & 0.3 & $\begin{array}{l}\text { Menceng sangat } \\
\text { halus }\end{array}$ & 7.48 & $\begin{array}{l}\text { Sangat runcing } \\
\text { sekali }\end{array}$ \\
\hline BR-06 & 1.46 & Terpilah buruk & 0.43 & $\begin{array}{c}\text { Menceng sangat } \\
\text { halus }\end{array}$ & 3.84 & $\begin{array}{l}\text { Sangat runcing } \\
\text { sekali }\end{array}$ \\
\hline BR-07 & 1.38 & Terpilah buruk & 0.54 & $\begin{array}{c}\text { Menceng sangat } \\
\text { halus }\end{array}$ & 4.68 & $\begin{array}{l}\text { Sangat runcing } \\
\text { sekali }\end{array}$ \\
\hline BR-08 & 0.74 & $\begin{array}{l}\text { Terpilah } \\
\text { sedang }\end{array}$ & 0.06 & $\begin{array}{l}\text { Menceng } \\
\text { simetris }\end{array}$ & 4.76 & $\begin{array}{l}\text { Sangat runcing } \\
\text { sekali }\end{array}$ \\
\hline BR-09 & 1.78 & Terpilah buruk & 0.56 & $\begin{array}{l}\text { Menceng sangat } \\
\text { halus }\end{array}$ & 3.09 & $\begin{array}{c}\text { Sangat runcing } \\
\text { sekali }\end{array}$ \\
\hline BR-010 & 0.93 & $\begin{array}{l}\text { Terpilah } \\
\text { sedang }\end{array}$ & -0.38 & $\begin{array}{c}\text { Menceng sangat } \\
\text { kasar }\end{array}$ & 3.31 & $\begin{array}{l}\text { Sangat runcing } \\
\text { sekali }\end{array}$ \\
\hline BR-011 & 1.71 & Terpilah buruk & 0.18 & Menceng halus & 2.18 & Sangat runcing \\
\hline BR-012 & 0.54 & $\begin{array}{l}\text { Terpilah } \\
\text { sedang }\end{array}$ & -0.17 & Menceng kasar & 6.53 & $\begin{array}{l}\text { Sangat runcing } \\
\text { sekali }\end{array}$ \\
\hline BR-014 & 0.66 & $\begin{array}{l}\text { Terpilah } \\
\text { sedang }\end{array}$ & -0.55 & $\begin{array}{c}\text { Menceng sangat } \\
\text { kasar }\end{array}$ & 9.2 & $\begin{array}{c}\text { Sangat runcing } \\
\text { sekali }\end{array}$ \\
\hline BR-015 & 1.5 & Terpilah buruk & 0.16 & Menceng halus & 2.7 & Sangat runcing \\
\hline BR-016 & 0.54 & $\begin{array}{l}\text { Terpilah } \\
\text { sedang }\end{array}$ & -0.17 & Menceng kasar & 5 & $\begin{array}{l}\text { Sangat runcing } \\
\text { sekali }\end{array}$ \\
\hline BRB-01 & 1.1 & Terpilah buruk & 0.89 & $\begin{array}{c}\text { Menceng sangat } \\
\text { halus }\end{array}$ & 3.51 & $\begin{array}{l}\text { Sangat runcing } \\
\text { sekali }\end{array}$ \\
\hline BRB-02 & 0.99 & $\begin{array}{l}\text { Terpilah } \\
\text { sedang }\end{array}$ & -0.82 & $\begin{array}{l}\text { Menceng sangat } \\
\text { kasar }\end{array}$ & 3.03 & $\begin{array}{l}\text { Sangat runcing } \\
\text { sekali }\end{array}$ \\
\hline BRB-03 & 1.31 & Terpilah buruk & 0.32 & $\begin{array}{l}\text { Menceng sangat } \\
\text { halus }\end{array}$ & 2.6 & Sangat runcing \\
\hline BRB-04 & 1.31 & Terpilah buruk & -0.01 & $\begin{array}{l}\text { Menceng } \\
\text { simetris }\end{array}$ & 2.87 & Sangat runcing \\
\hline BRB-05 & 1.66 & Terpilah buruk & -0.06 & $\begin{array}{l}\text { Menceng } \\
\text { simetris }\end{array}$ & 2.37 & Sangat runcing \\
\hline BRB-07 & 0.86 & $\begin{array}{l}\text { Terpilah } \\
\text { sedang }\end{array}$ & 0.44 & $\begin{array}{c}\text { Menceng sangat } \\
\text { halus }\end{array}$ & 6.24 & $\begin{array}{l}\text { Sangat runcing } \\
\text { sekali }\end{array}$ \\
\hline $\begin{array}{l}\text { BRB-08 } \\
\text { BRB-09 }\end{array}$ & $\begin{array}{l}1.33 \\
1.17\end{array}$ & $\begin{array}{l}\text { Terpilah buruk } \\
\text { Terpilah buruk }\end{array}$ & $\begin{array}{l}0.19 \\
-0.2\end{array}$ & $\begin{array}{l}\text { Menceng halus } \\
\text { Menceng kasar }\end{array}$ & $\begin{array}{l}2.62 \\
2.71\end{array}$ & $\begin{array}{l}\text { Sangat runcing } \\
\text { Sangat runcing }\end{array}$ \\
\hline $\begin{array}{l}\text { BRB- } \\
010\end{array}$ & 1.23 & Terpilah buruk & 0.14 & Menceng halus & 2.49 & Sangat runcing \\
\hline
\end{tabular}




\begin{tabular}{|c|c|c|c|c|c|c|}
\hline $\begin{array}{c}\text { BRB- } \\
011\end{array}$ & 1.79 & Terpilah buruk & 0.01 & $\begin{array}{l}\text { Menceng } \\
\text { simetris }\end{array}$ & 2.18 & Sangat runcing \\
\hline $\begin{array}{c}\text { BRB- } \\
012\end{array}$ & 1.35 & Terpilah buruk & 0.01 & $\begin{array}{l}\text { Menceng } \\
\text { simetris }\end{array}$ & 2.81 & Sangat runcing \\
\hline
\end{tabular}

\section{Hidrodinamika Daerah Penelitian}

Hasil validasi hasil permodelan didapatkan nilai RMSE sebesar $9.58 \%$, menurut Purwanto (2011) data hasil komputasi akan mengalami sedikit perbedaan dengan data lapangan, hal tersebut tidak menjadi masalah apabila kesalahan relatifnya tidak melebihi $50 \%$.

Berdasarkan hasil permodelan hidrodinamika didapatkan nilai kecepatan arus longshore berkisar antara 0-0.12 m.s. $\mathrm{s}^{-1}$ pada kondisi pasang purnama dan berkisar antara 0-0.08 m. $\mathrm{s}^{-1}$ pada kondisipasang perbani (Gambar 4), simulasi model dilakukan pada lokasi dekat pantai sehingga cukup mewakili pergerakan arus sepanjang pantai yang meningkat kecepatannya pada kondisi pasut purnama (Wisha et al., 2015). Berbeda dengan hasil pengukuran kecepatan dan arah arus di setiap stasiun pengambilan sampel, terlihat bahwa kecepatan arus bervariasi di setiap stasiun berkisar antara 0.014-0.486 m.s $\mathrm{s}^{-1}$ (Tabel 6), dengan kecepatan arus tertinggi berada pada stasiun BR 5, BR 7, BR 9, BR 11 dan BRB 2 yang berlokasi di wilayah yang jauh dari daratan, pada kecepatan arus yang lebih tinggi partikel sedimen yang telah mengalami resuspensi dan tertransport ke wilayah tersebut akan sukar mengendap dan akan terdistribusi oleh arus ke wilayah lain hingga terendapkan (Wisha dan Aida, 2016a), di stasiun lain kecepatan arus lebih rendah salah satunya untuk stasiun BR 16 , kecepatan arus pada stasiun tersebut hanya mencapai $0,06 \mathrm{~m} \cdot \mathrm{s}^{-1}$ dengan dominasi arah arus menuju ke Tenggara, kecepatan arus yang lemah tersebut mengakibatkan pengendapan sedimen semakin cepat karena perairan cenderung lebih tenang (Boer et al., 2005).

Di Perairan Brebes didominasi oleh arus pasang surut, terlihat pada Gambar 3 bahwa pasang surut yang terjadi di perairan Brebes berpengaruh terhadap kecepatan arus, antara data arus dan pasut memiliki korelasi fasa yang sama, dengan tipe pasang surut adalah campuran condong harian ganda, dalam 24 jam terjadi hampir 2 kali pasang dan 2 kali surut dengan rentang yang berbeda (Wisha et al., 2015), hal tersebut menyebabkan kecepatan arus pasut yang terjadi lebih variatif dan fluktuatif yang menyebabkan terjadinya perbedaan mekanisme pengangkutan dan pengendapan sedimen di setiap kondisi pasutnya (Hoekstra et al., 2002).

Dominasi arah arus bergerak ke arah timur dan timur laut (Tabel 4) hal tersebut sebanding dengan arah transpot dan pengendapan sedimen yang terjadi di Perairan Brebes, dominasi jenis sedimen dasar cenderung lanau sehingga ukuran sedimen sangat kecil dan mudah untuk teraduk dan terendapkan kembali, mengakibatkan peningkatan konsentrasi sedimen tersuspensi dan kekeruhan di perairan, dan secara langsung akan menghambat proses autotrofik yang ada di perairan (Wisha et al., 2016).

Pola arus sepanjang pantai yang terjadi di Perairan Brebes merupakan faktor utama penyebab abrasi, dengan kecepatan arus yang fluktuatif berdasar pada kondisi pasut yang ada menyebabkan beberapa wilayah mengalami abrasi dan wilayah lainnya mengalami akresi, hal tersebut realistis karena proses kesetimbangan pantai (continental drift) dimana terjadi kesetimbangan jumlah sedimen yang terangkut di wilayah abrasi dan di wilayah akresi (Walker et al., 2002). Proses pasang surut cukup berpengaruh dalam pengangkutan sedimen di muara, muara terbesar diwilayah kajian adalah Sungai Pemali yang cukup tinggi dalam memberikan masukan sedimen ke laut, pada saat pasang, level air laut lebih tinggi sehingga air laut cenderung mendominasi dan masuk kedalam sungai, dan sebaliknya, pada saat surut level air laut lebih rendah daripada level air sungai sehingga partikel-partikel dari dasar sungai terangkut oleh arus surut menuju muara dan laut (Wisha dan Aida, 2016a), muara sungai termasuk salah satu wilayah yang cukup signifikan dalam memberikan asupan sedimen ke laut (Hoekstra et al., 2002). 
Tabel 4. Kecepatan arus di setiap stasiun Pengambilan sampel

\begin{tabular}{|c|c|c|c|c|c|c|c|c|}
\hline $\begin{array}{l}\text { Kode } \\
\text { Stasiun }\end{array}$ & $\begin{array}{c}\text { Kecepat } \\
\text { an arus } \\
\left({\left.\mathrm{m} . \mathrm{s}^{-1}\right)}^{-1}\right.\end{array}$ & $\begin{array}{c}\text { Arah } \\
\text { arus } \\
\text { (Derajat) }\end{array}$ & $\begin{array}{l}\text { Kode } \\
\text { Stasiun }\end{array}$ & $\begin{array}{c}\text { Kecepat } \\
\text { an arus } \\
\left({\left.\mathrm{m} . \mathrm{s}^{-1}\right)}^{-1}\right.\end{array}$ & $\begin{array}{c}\text { Arah arus } \\
\text { (Derajat) }\end{array}$ & $\begin{array}{l}\text { Kode } \\
\text { Stasiun }\end{array}$ & $\begin{array}{c}\text { Kecepat } \\
\text { an arus } \\
\left(\mathrm{m}^{-1} \mathrm{~s}^{-1}\right)\end{array}$ & $\begin{array}{c}\text { Arah } \\
\text { arus } \\
\text { (Derajat) }\end{array}$ \\
\hline BR-00 & 0.225 & $\begin{array}{l}\text { Barat } \\
\text { daya }\end{array}$ & BR-011 & 0.380 & $\begin{array}{l}\text { Timur } \\
\text { laut }\end{array}$ & BRB-07 & 0.045 & Timur \\
\hline BR-01 & 0.125 & Timur & BR-012 & 0.136 & Barat laut & BRB-08 & 0.094 & Timur \\
\hline BR-02 & 0.105 & Timur & BR-014 & 0.128 & Barat laut & BRB-09 & 0.032 & Timur \\
\hline BR-03 & 0.135 & Timur & BR-015 & 0.160 & Timur & BRB-010 & 0.016 & Timur \\
\hline BR-05 & 0.440 & $\begin{array}{l}\text { Timur } \\
\text { laut }\end{array}$ & BR-016 & 0.060 & Tenggara & BRB-011 & 0.014 & Timur \\
\hline BR-06 & 0.165 & Timur & BRB-01 & 0.013 & Timur & BRB-012 & 0.015 & Timur \\
\hline BR-07 & 0.400 & $\begin{array}{l}\text { Timur } \\
\text { laut }\end{array}$ & BRB-02 & 0.486 & $\begin{array}{l}\text { Barat } \\
\text { daya }\end{array}$ & & & \\
\hline BR-08 & 0.150 & Timur & BRB-03 & 0.453 & $\begin{array}{l}\text { Barat } \\
\text { daya }\end{array}$ & & & \\
\hline BR-09 & 0.380 & $\begin{array}{l}\text { Timur } \\
\text { laut }\end{array}$ & BRB-04 & 0.080 & Timur & & & \\
\hline BR-010 & 0.132 & $\begin{array}{c}\text { Barat } \\
\text { laut }\end{array}$ & BRB-05 & 0.081 & Barat laut & & & \\
\hline
\end{tabular}

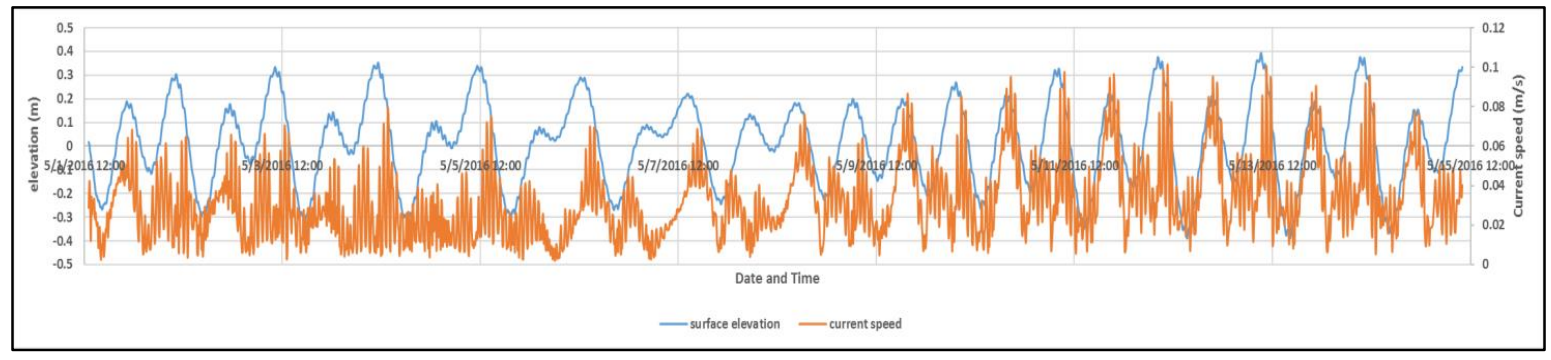

Gambar 4. Hasil permodelan hidrodinamika Perairan Brebes

\section{Mekanisme Sedimen \\ Sistem \\ Pengendapan}

Proses pengendapan sedimen di perairan Kecamatan Brebes dapat diperkirakan berdasarkan data hasil analisis granulometri dan statistik sedimen. Karakteristik ukuran butir sedimen digunakan untuk menafsirkan sebaran dan mekanisme pengangkutan dan pengendapan sedimen di suatu kawasan (Korwa et al., 2013). Secara umum jenis sedimen daerah penelitian di dominasi oleh partikel ukuran butir halus yaitu lanau hingga kasar (pasir). Berdasarkan ukuran butir sedimen tersebut menggabarkan bahwa kondisi perairan pada Kecamatan Brebes saat sedimen tersebut mengendap di pengaruhi oleh kecepatan arus kuat dicirikan dengan ukuran partikel kasar, sedangkan partikel ukuran halus dicirikan oleh arus yang lemah. Ukuran butir merupakan indikasi besar/kuatnya kekuatan arus dan gelombang yang bekerja pada lingkungan pengendapan tersebut (Rifardi et al., 1998). Nilai sortasi mengindikasikan tipe pengendapan, karakteristik arus pengendapan dan kecepatan waktu pengendapan (Solahuddin et al., 2006). Sedimen yang tersebar dan diendapkan di perairan daerah penelitian menunjukkan bahwa sedimen memiliki waktu yang pendek untuk mengendap ditunjukkan dengan tingginya nilai sortasi (terpilah buruk hingga sedang) menunjukkan keseragaman butir sedimen yang kecil.

Ukuran butir sedimen daerah penelitian masuk dalam fraksi kasar hingga halus sehingga dapat diinterpretasikan bahwa jenis mekanisme transportasi sedimen berupa bedload dan suspension (suspensi). Mekanisme transportasi bedload terjadi pada fraksi yang kasar melalui pergerakan 
transportasi arus traksi dalam bentuk rolling (menggelinding), sliding (terseret), creep (merayap) dan saltasi. Suspension load bekerja mengangkut sedimen halus (lempung, lanau hingga pasir sangat halus) berbentuk suspensi yang terangkut cukup jauh dalam aliran, sebelum pada akhirnya mengendap dengan kecepatan arus yang melemah (Nugroho dan Basit, 2014). Kondisi perairan laut Kecamatan Brebes sangat dipengaruhi oleh keberadaan muara sungai, dimana muara sungai sangat dipengaruhi oleh kondisi debit sungai dan pasang-surut air laut. Disaat kondisi pasang energi arus sungai yang bertemu dengan air laut akan melemah dibagian muara sehingga tercampur endapan sungai dengan endapan laut dengan fraksi sedimen kasar. Namun disaat kondisi surut dan arus sungai melemah di bagian muara sehingga hanya fraksi halus berukuran lempung hingga lanau yang akan terendapkan. Sehingga pada bagian Timur daerah penelitian cenderung terendapkan sedimen halus lanau - lanau pasir (Gambar 5). Bagian Barat terendapkan material sedimen berukuran lebih kasar yaitu pasir hingga pasir lanauan. Kondisi tersebarnya ukuran butir lebih kasar menuju laut terbuka juga berpotensi membawa dampak semakin terjadinya proses pengikisan di daerah pantai (Bayhaqi dan Dungga, 2015), dalam kasus ini terjadi pengikisan pada daerah beting gisik (pulau pasir) yang ada di daerah penelitian.

Adanya sedimen berukuran kasar menunjukkan bahwa arus dan gelombang pada daerah ini relatif kuat, fraksi kasar yang tersebar pada bagian Barat daerah penelitian umumnya diendapkan pada daerah terbuka yang berhubungan dengan laut lepas, sedangkan sedimen halus diendapkan pada arus dan gelombang dengan energi lemah dan tenang yaitu pada bagian dekat darat dan muara sungai. Pada bagian Timur dan bagian Barat yang berdekatan dengan muara sungai didominasi oleh jenis sedimen lanau lanau pasiran. Hal ini disebabkan karena letaknya yang lebih jauh dari lautan lepas dan terlindung dari pengaruh arus yang kuat serta banyak bahan organik dan detritus yang dibawa air sungai dan menumpuk di perairan ini, terutama pada saat arus melemah yang disebabkan oleh keberadaan kawasan mangrove.

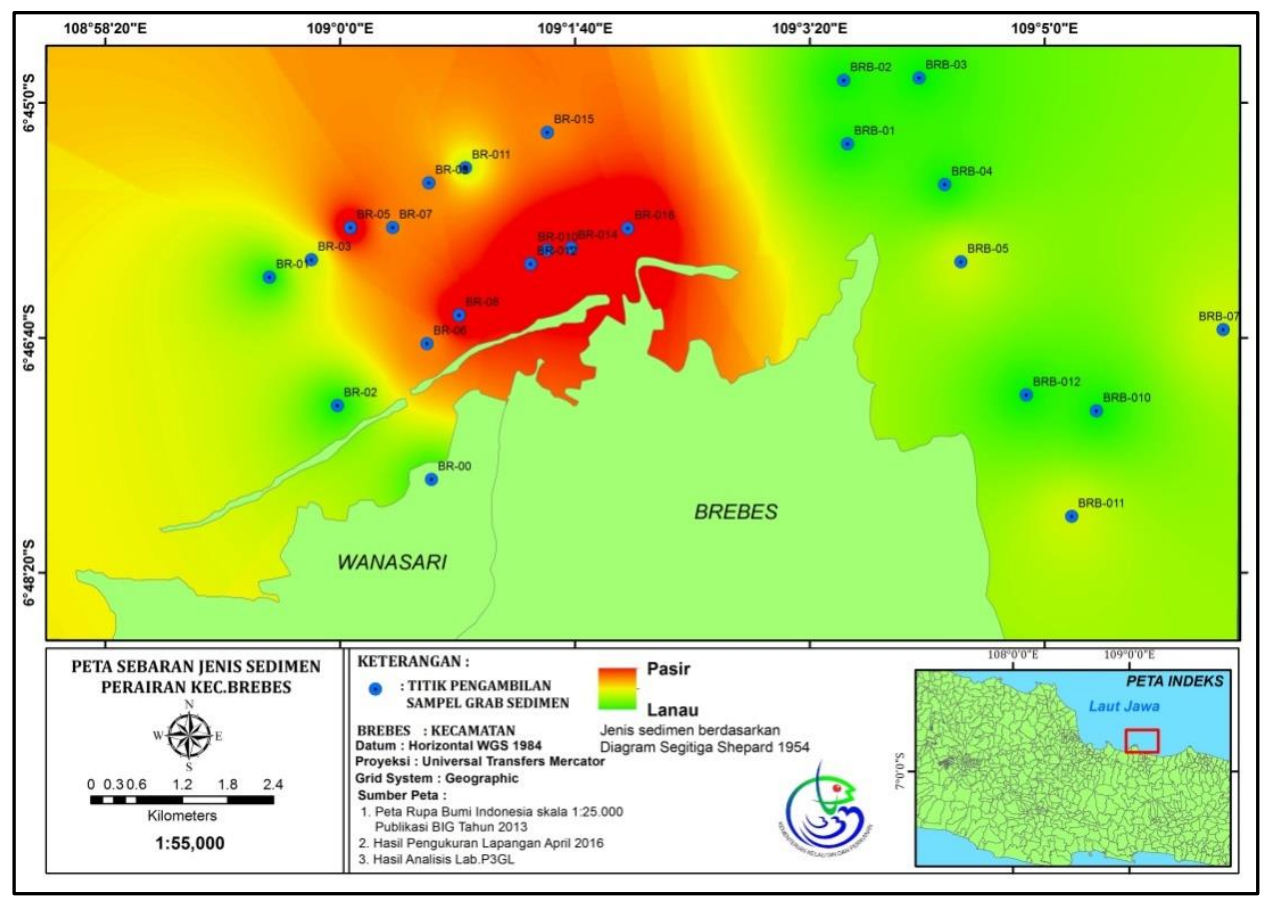

Gambar 5. Peta sebaran jenis sedimen di perairan Kec. Brebes

Kawasan pesisir Kecamatan Brebes memiliki kawasan mangrove yang sangat luas, kondisi tersebut yang menjadi salah satu faktor mengurangi kecepatan arus dan gelombang sehingga dekat kawasan tersebut hanya terendapkan fraksi berukuran halus. 
Perbedaan tingkat kerapatan vegetasi mangrove akan menyebabkan perbedaan kecepatan arus akibat kemampuan perakaran mangrove yang mempu mengakumulasi atau merangkap sedimen (Roza, 2016). Menurut Kennish (2000), perakaran mangrove yang mampu mengakumulasi sedimen, merangkap serasah dan berperan dalam pembentukan formasi tanah. Selanjutnya Nontji (2002) menambahkan bahwa ekosistem mangrove memiliki akar-akar yang kokoh dan dapat meredam pengaruh gelombang serta menahan lumpur atau sedimen halus sehingga lahan mangrove bisa menjadi semakin luas serta mempercepat terbentuknya tanah atau endapan sedimen untuk ditumbuhi mangrove.

\section{KESIMPULAN}

Jenis sedimen berdasarkan hasil analisis granulometri terhadap sampel sedimen dasar perairan di Kecamatan Brebes terdapat 4 jenis sedimen menurut ukuran butirnya yaitu pasir, pasir lanauan, lanau pasiran dan lanau. Sebaran sedimen bagian Timur daerah penelitian didominasi oleh fraksi halus berupa lanau hingga lanau pasiran, sedangkan bagian Barat daerah penelitian didominasi oleh fraksi kasar, pasir hingga pasir lanauan. Kondisi hidro-oseanografi daerah penelitian mencirikan bahwa arus dan gelombang sangat fluktuatif sehingga terekam dalam klasifikasi sortasi butiran yang masuk dalam kelas pemilahan buruk hingga sedang. Mekanisme transportasi sedimen pada fraksi halus (lempung sampai lanau pasiran) pengangkutan secara suspension load dalam bentuk suspensi.

Kecepatan arus bervariasi di setiap stasiun arus tertinggi berada pada stasiun yang berlokasi di wilayah yang jauh dari daratan. Kecepatan arus lebih rendah salah satunya untuk stasiun BR 16 hanya mencapai 0,06 m.s-1 dengan kecepatan arus yang lemah tersebut mengakibatkan pengendapan sedimen semakin cepat karena perairan cenderung lebih tenang dan mengendapkan partikel sedimen halus seperti lanau.Pola arus sepanjang pantai yang terjadi di Perairan Brebes merupakan faktor utama penyebab abrasi, dengan kecepatan arus yang fluktuatif berdasar pada kondisi. Upaya mitigasi yang perlu dilakukan dengan kondisi tersebut dengan melakukan penilaian terhadap efektifitas bangunan pelindung pantai yang telah ada, dan melakukan sistem pembelokan/pengalihan sungai serta pengaturan sistem aliran sungai sehingga terjadi keseimbangan pengendapan sedimen pada bagian pesisir yang mengalami abrasi.

\section{UCAPAN TERIMAKASIH}

Penulis menyampaikan terima kasih kepada Loka Penelitian Sumber Daya dan Kerentanan Pesisir (LPSDKP) Balitbang KP atas DIPA Anggaran Penelitian tahun 2016 terkait penelitian yang dilakukan di Kecamatan Brebes. Serta kepada DKP Kab. Brebes dan Kelompok Mangrove Pandansari yang telah membantu dalam proses pengambilan data dilapangan. Ucapan terimakasih juga kami sampaikan kepada pihak-pihak yang telah bersedia memberikan koreksi, kritik, saran dan masukan sehingga peneliti dan penulisan ini dapat terselesaikan.

\section{DAFTAR PUSTAKA}

Abuodha, J. O. Z. (2003). Grain size distribution and composition of modern dune and beach sediments, Malindi Bay coast, Kenya. Journal of African Earth Sciences, 36(1), 41-54. Doi: 10.1016/S0899-5362(03)000162.

Arjenggi, E. K., Muzahar, M., Yandri, F. (2013). Karakteristik Sedimen Permukaan Dasar di Perairan Kelurahan Tarempa Barat Kecamatan Siantan Kabupaten Anambas. Jurusan IImu Kelautan. Universitas Maritim Raja Ali Haji.

Badan Pusat Statistik Kecamatan Brebes. (2015). Kecamatan Brebes Dalam Angka. Kabupaten Brebes. 295p.

Bayhaqi, A., \& Dungga, C. M. (2015). Distribusi butiran sedimen di pantai Dalegan, Gresik, Jawa Timur. DEPIK, 4(3).

Doi:10.13170/depik.4.3.3054.

Blott, S. J., \& Pye, K. (2001). GRADISTAT: a grain size distribution and statistics package for the analysis of unconsolidated sediments. Earth surface processes and Landforms, 26(11), 1237-1248. Doi: 10.1002/esp.261.

Boer, W., Bergh, G. D. V. D., Haas, H. D., Stigter, H. C. D., Gieles, R., \& Weering, T. C. E. (2005). Validation of Acculutaion Rates in Teluk Banten 
(Indonesia) from Commonly Applied ${ }^{210} \mathrm{~Pb}$ Models, Using the 1883 Krakatau Tephra as Time Maker. J. Mar. Geo. Geochemist. Geophys., 227, 263-277.

Doi: 10.1016/J.margeo.2005.12.002.

Bui, E. N., Mazzullo, J. M., \& Wilding, L. P. (1989). Using quartz grain size and shape analysis to distinguish between aeolian and fluvial deposits in the Dallol Bosso of Niger (West Africa). Earth Surface Processes and Landforms, 14(2), 157-166. Doi: 10.1002/esp.3290140206.

Darlan, Y. (1996). Geomorfologi wilayah pesisir. Aplikasi untuk penelitian wilayah pantai. Pusat Pengembangan Geologi Kelautan. Bandung. 96p.

Davis Jr. (1991). Oceanography: An Introduction to the Marine Enviroment. Wm.C. Brown Publisher. Iowa.USA. 516p.

Dinas Kelautan dan Perikanan Brebes (2008). Coastal Spatial Planning of Brebes Regency. 56p.

Dinas Kelautan dan Perikanan Provinsi Jawa Tengah (2012). Coastal Planning and Zoning Small Island Central Java. 135p.

Dinas Perikanan dan Kelautan Kabupaten Brebes (2015). Penyusunan Rencana Tata Ruang Pesisir Kabupaten Brebes. 67p.

Diposaptono, S., \& Budiman (2007). Hidup Akrab dengan Gempa dan Tsunami. PT Sarana Komunikasi Utama. Bogor. 383 p.

Djuri, M., Samodra, H., Amin, T. C., \& Gafoer, S. (1996). Peta Geologi Lembar Purwokerto dan Tegal, Jawa. Pusat Penelitian dan Pengembangan Geologi. Bandung.

Dyer, K. (1986). Coastal and estuarine sediment dynamics. Jhon Wiley and Sons. Chichester. 324p.

Folk, R. L., \& Ward, P. B. (1977). Student operator error in determination of roundess, spherity and grain size. Sed Petrology, 25, 297-301p.

Folk, R. L., \& Ward, W. C. (1957). Brazos River bar: a study in the significance of grain size parameters. Journal of Sedimentary Research, 27(1). Doi: 10.1306/74d70646-2b21-11d7$8648000102 \mathrm{c} 1865 \mathrm{~d}$.

Friedman, G. M. (1979). Differences in size distributions of populations of particles among sands of various origins: addendum to IAS Presidential Address. Sedimentology, 26(6), 859-862. Doi: 10.1111/j.1365-091.1979.tb00979.x.

Helfinalis, Pramudji, \& Hadikusumah (2010). Studi Kelayakan Pembangunan Dermaga di Lingkungan Perairan Pantai Ujung Gebang Indramayu, Laporan Akhir Program Insentif Peneliti dan Perekayasa LIPI tahun 2010. Pusat Penelitian Oseanografi, Lembaga IImu Pengetahuan Indonesia. Jakarta. 44p.

Hoekstra, P., Lindeboom, H., Bak, R., Bergh, G. V. D., Tiwi, D. A., Douven, W., \& Meesters, E. (2002). Teluk Banten Research Programme: an integrated coastal zone management Study. Staple (Ed.) Scientific programme Indonesia-Netherlands Proceedings of a workshop held on February 12th 2002. Bandung. Indonesia. p, 59-70.

Hsieh, H. L. (1995). Spatial and temporal patterns of polychaete communities in a subtropical mangrove swamp: influences of sediment and microhabitat. Marine Ecology Progress Series, 127, 157-167. Doi: 10.3354/meps127157.

Hubbard, J. A., \& Pocock, Y. P. (1972). Sediment rejection by recent scleractinian corals: a key to palaeoenvironmental reconstruction. Geologische Rundschau, 61(2), 598626. Doi: 10.1007/BF01896337.

Ingmanson, D. E., \& Wallace. W. J. (1989). Oceanography an Introduction. Fouth Edition. Wadsworth Publishing Company. Belmont, California. 541p.

Junaidi \& Wigati, R. (2011). Analisis parameter statistic butiran sedimen dasar pada sungai alamiah (studi kasus Sungai Krasak Yogyakarta). Wahana Teknik Sipil, 16(2), 46-57.

Kennish, M. J. (2000). Practical handbook of marine science. CRC Press.

Korwa, J. I. S., Opa, E. T., \& Djamaludin, R. (2013). Karakteristik sedimen litoral di pantai Sindulang Satu. J. Pesisir dan Laut Tropis, 1(1), 48-54.

Mackay, P. (2012). The Brebes Mangrove Restoration \& Reforestation for Climate Change Adaptation Project; Central Java Green Belt Mangrove Corridor Program, Brebes 
Regency. Bappeda Kabupaten Brebes. 67p.

Nontji A. (2002). Laut Nusantara. Jakarta (ID): Djambatan Pr.

Nugroho, S. H., \& Basit, A. (2014). Sebaran Sedimen Berdasarkan Analisis Ukuran Butir di Teluk Weda, Maluku Utara. Jurnal IImu dan Teknologi Kelautan Tropis, 6(1), 229-240.

Pettijohn, F. G., Potter, P. D., \& Siever, R. (1972). Sand and Sandstone. Springer, New York. 618p.

Purwanto, P. (2011). Analisa Spektrum Gelombang Berarah di Perairan Pantai Kuta, Kabupaten Badung, Bali. Buletin Oseanografi Marina, 1(1), 45-59.

Rifardi, Oki, K., \& Tomiyasu, T. (1998). Sedimentary Environments Based on Texture Surface Sediments and Sedimentation Rates in the South Yatsushiro (Sea), Soutwest Kyushu, Japan. Jour. Sedimentol. Soc. Japan, 48, 67-84.

Rifardi. (2012). Geologi Sedimen Modern (Edisi revisi). Universitas Riau Press.

Shepard, F. P. (1954). Nomenclature based on sand-silt-clay ratios. Journal of Sedimentary Research, 24(3). Doi: 10.1306/d4269774-2b26-11d78648000102c1865d.

Solahuddin, T., Triarso, E., \& Troa, R. S. (2006). Sebaran dan Dinamika Sedimen Pantai Moutong Perairan Teluk Tomini Sulawesi Tengah. Jurnal Segara, 2(2), 42-48.

Surbakti, H. (2010). Pemodelan sebaran sedimen tersuspensi dan pola arus di pesisir Banyuasin, Sumatera Selatan (Thesis). Institut Pertanian Bogor. Bogor.

Suyono. (2015). Strategi Penanganan Kerusakan Mangrove di Wilayah Pantai Kabupaten Brebes Propinsi Jawa Tengah. (Disertasi). Program Doktor Manajemen Sumber Daya Pantai Program Pasca Sarjana Universitas Diponegoro.

Walker, L. J., Wilkinson, B. H., \& Ivany, L. C. (2002). Continental drift and Phanerozoic carbonate accumulation in shallow-shelf and deep-marine settings. The Journal of Geology, 110(1), 75-87. Doi: $10.1086 / 324318$

Wentworth, C. K. (1922). A scale of grade and class terms for clastic sediments.
The Journal of Geology, 30(5), 377392. Doi: $10.1086 / 622910$.

Winter, C. (2007). On the evaluation of sediment transport models in tidal environments.

Sedimentary Geology, 202(3), 562-571.

Doi:10.1016/j.sedgeo.2007.03.019.

Wisha, U. J., \& Aida, H. (2016a). Analysis of Tidal Range and Its Effect on Distribution of Total Suspended Solid (TSS) in the Pare Bay Waters. Jurnal Kelautan, 9(1), 23-31.

Doi: 10.21107/jk.v9i1.1066.

Wisha, U. J., \& Aida, H. (2016b). Bathymetry and Hydrodynamics in Pare Bay Waters During Transitional Seasons (September October). OmniAkuatika, 12(2).

Doi: 10.20884/1.oa.2016.12.2.98.

Wisha, U. J., Yusuf, M., \& Maslukah, L. (2016). Kelimpahan Fitoplankton Dan Konsentrasi TSS Sebagai Indikator Penentu Kondisi Perairan Muara Sungai Porong. Jurnal Kelautan, 9(2), 122-129.

Doi: 10.21107/jk.v9i2.1298.

Wisha, U. J., Husrin, S., \& Prihantono, J. (2015). Hydrodynamics Banten Bay During Transitional Seasons (August-September). IImu Kelautan, 20(2), 101-112.Doi: 10.14710/ik.ijms.20.2.101-112.

Yasin A. M., Sukiyah E, \& Isnaniawardhani, V. (2016). Grain Size Analysis of Quartenary Sediment from Kendari Basin, Indonesia. International Journal of Science and Research, 5(11), 1748-1751.

Doi: 10.21275/ART20163165.

Yenica, R. S. (2016). Kontribusi Mangrove Dalam Memerangkap Sedimen Di Wilayah Pesisir Kota Dumai Provinsi Riau (Thesis). Institut Pertanian Bogor. Bogor. 